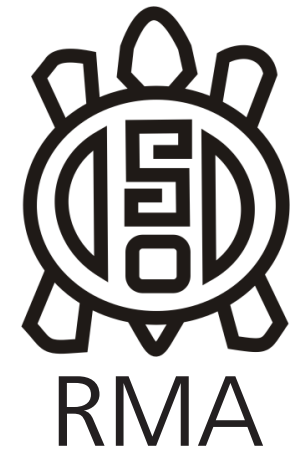

Dossier

\title{
The Value of Narrative: Memory and Patrimony among the Siona
}

\author{
El valor de la narrativa: memoria y patrimonio entre los Siona
}

\author{
Esther Jean Langdon
}

Programa de Pós-Graduação em Antropologia Social, Universidade Federal de Santa Catarina, Brazil. E-mail: estherjeanbr@gmail.com

\begin{abstract}
This paper explores the value of narrative of the Siona Indians of Colombia as cultural patrimony and expression of ethics and aesthetics of daily life, collective memory and identity. It focuses on a group of narratives collected in the 1960s by a young Siona man, Felinto Piaguaje, who learned to write his language. Five of these were presented in a workshop in 2014 that intended to collaborate with the ongoing language revitalization and ethnoeducation projects of this Western Tukanoan speaking group. Two of the narratives examined in the workshop are analyzed, as well as the discussions and performances that they stimulated. The participating elders emphasized their value for collective memory regarding their perspective of the world and need for their preservation as cultural patrimony. The young teachers expressed the value of the narratives for educational activities and ethnic identity because they reference their own tradition and language in a context of rapid change. Siona narrative tradition continues to invoke their perspective of a fractal universe as well as philosophy of living well. In addition, in the contemporary situation, these narratives represent the expression of identity for the Siona, conveying information about who they are to themselves and others.
\end{abstract}

Keywords: narrative, memory, ethnic identity, language revitalization, Siona Indians

\begin{abstract}
Resumo
Este trabalho explora o valor da narrativa dos índios Siona da Colômbia como o patrimônio cultural e a expressão da ética e estética da vida cotidiana, memoria coletiva e identidade. Ele enfoque num grupo de narrativas registrados na década de 1960 por um joven siona, Felinto Piaguaje, que aprendeu escrever seu idioma. Cinco destas que foram apresentadas numa oficina em 2014 realizada com a intenção de colaborar com os projetos em curso sobre a revitalização da linguagem e entoeducação deste grupo de falantes do tucano ocidental. Duas narrativas examinadas na oficina são analisadas e também as discussões e performances evocados por elas. Os anciões que participaram na oficina enfatizaram o valor destas para a memória coletiva da sua perspectiva do mundo e a necessidade da sua preservação como patrimônio cultural. Os jovens professores expressaram o valor das narrativas para as atividades educacionais e para sua identidade étnica por referenciar sua própria tradição e linguagem num contexto de mudança rápida. Sua tradição narrativa continua a invocar sua perspectiva de um universo fractal e também a filosofia de bem viver. Na situação contemporânea, ela também expressa a identidade para os Siona, transmitindo informação sobre quem eles são para si mesmo e para os outros.
\end{abstract}

Palavras Chaves: narrativa, memória, identidade étnica, revitalização da língua, índios Siona

Although much has been said and written about the relation of myth to ritual and its expression of Amerindian philosophy, ontology and cosmogony, much less attention has been given to the praxis of narrative performance as a communicative event that evokes memory and conveys to the listeners the aesthetics and ethos of daily life. An important exception is the publication of Hipólito CandreKinerai's poetic teachings that seek to foster the welfare and growth of his children and family. These teachings, complied by Juan Alvaro Echeverri (Candre and Echeverri 1993, 1996), are recommendations and instructions for proper living and well-being. Told by a Uitotoan sage in a performance setting, they consist of advice about daily tasks, responsibilities of mothers and fathers, cultivation of plants, care of children and proper relations.

Performance of narrative in family and public settings as council for living well is not unique to the Uitotos, but is also a tradition among the Western Tukanoan groups that occupy the northwest Amazonia shared by Colombia, Ecuador and Peru (Belaunde 2001; Bellier 1991; Cipolletti 1988; Langdon 2014; Vickers 1989). The Siona Indians of the upper Putumayo River have a large corpus of narratives that play a similar role to the 
counseling poetry of the Uitoto as a guide for proper action and well-being (Langdon 2001). They cover a number of themes regarding the aesthetics and ethics of the sociality of daily life (Overing and Passes 2000), such as adequate gender behavior, social roles of husband or wife, annual cycles, work activities, parenting, etc., and should be considered as "equipment for living" (Burke 1957), in that they affirm and describe events and customs of daily life that set models for collective wellbeing. Upon first glance, they appear as more normative and less dramatic than shamanic narratives that relate encounters with the invisible side of reality (Langdon 2013) or tell of the great shamanic battles of the past (Langdon 1990). However, they are far more than forms of "folklore" or static vestiges of a disappeared past and have important contemporary relevance. The narratives continue to index important information about Siona ontology in the contemporary context and are valued as cultural patrimony and cultural identity.

The traditional performance context for narration among the Siona was early morning, when the family rose before dawn and drank the stimulant yoco (Belaunde and Echeverri 2008; Echeverri 2004). As they sat together weaving baskets and making other objects, they exchanged dreams and narratives that had significance for ongoing events. Good story telling was a capacity of most elders and not limited to particular males or females. This performance context has long disappeared given the dramatic changes and violence the Siona have been subjected to over the last 40 years. Not only have many migrated to urban centers, but also daily routine has been significantly altered for those in the rural communities. However, they have long recognized the importance of these narratives as cultural patrimony and currently are searching for new contexts of performance in an effort to revitalize their language and culture. An important actor in this effort to continue the narrative tradition is Felinto Piaguaje, who as a youth in the 1960s registered narratives told by elders and later became an important narrator and researcher for the ethnoeducational project designed by the Cabildo Association of Siona Peoples ACIPS (Asociación de Cabildos de los Pueblos Siona). This article honors Felinto's life-long efforts to preserve the Siona narrative tradition and the experience of presenting them in a language revitalization workshop organized in 2014. The corpus of texts that he collected not only serves as evidence of past ways of living well, but continues to transmit principles of Siona ontology. To illustrate this, I examine two of his narratives reviewed in the workshop on language revitalization and discuss the value and meaning that these narratives had for the participants in this new context. Their narrative tradition continues to invoke their perspective of a fractal universe as well as philosophy of living well. In the contemporary situation, these narratives represent also the expression of identity for the Siona, conveying information about who they are to themselves and others.

\section{Felinto's Narratives}

Luis Felinto Piaguaje was born in 1943 and attended the Catholic boarding school in Puerto Asis for four to five years during the 1950s. During his youth he stayed for an extended period with his grandfather Arsenio Yaiguaje, the last cacique-curaca (shaman leader) of the community of Buena Vista on the Putumayo River. As an elder and master shaman, Arsenio Yaiguaje counseled and taught Felinto and other youth, narrating legends and myths that instruct and give council on shamanic and daily practices and leading yajé (Banisteriopsis sp.) rituals. During his youth, early morning narrative performance was still part of daily life, and Felinto became familiar with a very large corpus of narratives. In 1959, at the age of 16, he volunteered to work as linguistic informant in Bogotá with Manuel Casas Manrique. Casas Manrique, associated with the Instituto Colombiano de Antropologia e Historia (ICANH), was a dedicated scholar and polyglot who studied numerous indigenous languages during his life. ${ }^{1}$ Felinto says that it was difficult to adapt at first, but he adjusted and stayed for approximately five years, learning to read and write his native language. During this time, he also served as an informant for two anthropologists, demonstrating evidence of his knowledge of shamanic rituals and Siona cosmology (Mallol de Recasens 1963; Mallol de Recasens and Recasens T. 1964-5). Upon his return, he registered over 40 narratives collected from the elder members of his community.

Knowing that I was spending much of my time recording and translating narratives, ${ }^{2}$ Felinto volunteered in 1972 to share the texts that he had registered. He spent long hours patiently dictating as I wrote. Of the texts that Felinto had collected, I registered 27 . Those that I did not record were descriptions of daily activities such as going to the garden or fishing, similar to those published by Wheeler (1987), that have a discursive form without narrativizing. The narratives that he shared with me range from the origin of yajé, mythic times, dreams, animal stories and ethnohistory to practices of daily sociality and customs, such as dances and other festivities. His narrators were twelve elders (eight males and four females) adept in the poetic performative tradition. Most narratives were part of group's repertoire known to most, rather than personal shamanic encounters. A common feature to many is the keying of the performance, in which the narrator contextualizes how the events recounted were

\footnotetext{
${ }^{1}$ His extensive study of Siona grammar was never was published and most of his notes were lost or destroyed after his death in 1973. I located one manuscript in the archives of the Centro de Investigaciones Lingüísticas y Etnográficas de la Amazonía Colombiana (CILEAC) in Bogotá of a linguistic survey made with Siona from the settlements of Orito and Comandante Playa on the Putumayo (Casas-Manrique and Castellví, 1940ms.).

2 Copies of the over 100 narratives recorded were left with the Instituto Colombiano de Antropologia e Historia (ICANH). The originals are in the Indiana University Folklore Archives with proper storage environment. In 2012, I was unable to locate the tapes left in Colombia.
} 
known, establishing time, location and whether told by others or through personal experience (evidenciality). Another striking characteristic of many is the closure in which the narrator expressed a sense of loss and laments the passing of the practices and customs related.

\section{Recent History and Etnographic Context}

I began my fieldwork in 1970 when petroleum exploration was developing in the region, and the Siona had become a minority in their ancestral territory. The Spaniards first entered their territory in the $17^{\text {th }}$ Century searching for gold and then the Franciscan missionaries attempted to establish missions along the river for some 150 years. This resulted in a series of epidemics and battles that reduced the some 8000 Western Tukanoans on the Putumayo to around 1000 by the late $19^{\text {th }}$ Century. Rubber collecting and other extractive activities brought renewed interest to the Putumayo in the 1880s, and by 1922, their population had been drastically reduced to around 250 individuals dispersed along the river in nucleated settlements. By 1970, they numbered around 300 (Wheeler 1987) along the Putumayo River in small settlements of families intermingled with or surrounded by colonist neighbors. Buena Vista was the largest community and the only recognized reserve, with 22 families numbering approximately 140 individuals. When I arrived, the Siona were in a process of increasing integration into the local economy and were abandoning their language, shamanic rituals and other traditional practices.

Cocaine and guerilla activities began in the late 1970s. The 1990s, marked by increased cocaine production and a new wave of immigrants, was the most violent, as new actors arrived to dispute control of the region, among them paramilitaries and drug lords from Medellin and Cali. Guerillas, controlling much of the region in the 1990s became known as a "third drug cartel" (Ramírez 201l: 54), and prevented to a certain extent the expansion of petroleum extraction. The Siona were caught in the crossfire, suffering violence and assassinations from all sides as well as irreparable environmental degradation, due to bombings and landmines in their territories (Corte Constitucional 2009). In 1994, areal fumigation of coca plantations with the toxic herbicide glyphosate began and increased significantly during the next 10 years. In spite of adverse health and environmental impacts, spraying has continued until the present, including the fumigation of indigenous resguardos or reserves. In the face of this violence, Siona families began to migrate in the late 1990s to the urban areas of Puerto Asis and Mocoa, living in conditions of poverty without adequate sanitation or health services (Kienzl 2006).

The situation in the Putumayo remains critical, although coca production and guerrilla activities have been reduced. Auto 004 of the Corte Constitucional (2009) declared the Siona to be physically and culturally endangered because of the violence and displacement. However, the Siona are struggling to survive as an ethnic group and have grown as a political force since the Constitution of 1991 that recognizes the pluriethnic and multicultural character of the State, granting indigenous peoples increased rights and autonomy. The Constitution grants collective ownership of indigenous territories, called resguardos, with the right to use and govern them as they see fit. In addition, the Constitution establishes the cabildo as the form of indigenous governance.

In 1970 Buena Vista was the only reserve. Today there are six Siona resguardos and 12 cabildos. The most recent census reports a total of 2,578 Siona (ACIPS 2011: 40). This growth is due to the "re-ethnization" process among mestizos in the region in the face of the heightened status of the indigenous peoples (Chaves Chamorro 2002, 2003), not increased birthrate. While in 1970 mestizo identity received higher status than that of the indigenous, the new constitution has caused a reversal, and many people are rediscovering and identifying with their indigenous roots. Buena Vista has grown from the 22 families in 1970 to 161 (ACIPS 2011:40). Although the original families of Buena Vista internally distinguish between themselves as ancestral occupants of their territory and the "recently arrived", the identification of the newcomers as Siona is an important political strategy for the group. Two of the most recent cabildos are found in the cities of Puerto Asis and Mocoa, created by displaced families because of the violence and environmental destruction. ${ }^{3}$ They have not lost ties with their home territories, and there is constant movement between the indigenous rural communities and urban areas (Musalem 2015).

In 2003, the Associación de los Cabildos de los Pueblos Indigenas (ACIPS) was created with headquarters in Mocoa. As a pan-Siona association, its primary goals are those of promoting culture, values and traditional norms outlined in the Plan de Vida (Portela Guarín, et. al 2003) and representing the interests of the communities whose cabildos belong to the Association. ACIPS serves as an important mediator between communities and Governmental and non-governmental organizations, and its survival is dependent upon the harnessing of external funding (Musalem 2015). They have designed a number of projects that have received financing, initiating with the first Life Plan (Portela Guarín, et. al 2003) funded by the Plan Nacional de Rehabilitación - PNR. Subsequent projects supported by national and international agencies have aimed to revitalize traditional agriculture practices, food habits, family and community organization, to train indigenous leaders, and to create an ethnoeducational curriculum (ACIPS 2014).

\footnotetext{
3 For instance, in 2013 the guerrillas broke an agreement with the Siona of Buenavista and invaded the resguardo, forcing more families to flee to Mocoa and Puerto Asis.
} 


\section{Narrative and Collaborative Anthropology}

I left the Putumayo in 1974 and returned various times for shorter trips. In 1992, Felinto and I talked about revising and correcting the narratives for purposes of publication in his name and in honor of his teacher. But because of the violence, I did not return to the Putumayo for 18 years. In 2011 I managed to make contact with Felinto in hopes of finally preparing his manuscripts for publication. With the support of Professor Hugo Portela of the Universidad del Cauca, we met during several days in 2012 in Popayan, revising my copies of the texts, since his hand-written notes had long been lost. His interest revising and preparing the texts was evident. He told me that in 2004 he attended a course in ethnolinguistics sponsored by the Minister of Education and that he was currently serving as consultant for the ethnoeducational project in charge of gathering texts to be used in teaching the teachers and students Siona. Later I learned more about this project that been designed by ACIPS from the educational consultant. She told me that Felinto was a key figure during the four years that it was funded by the Minister of Education. Together with the consultant and other taitas $^{4}$ (elder/shaman), Felinto journeyed to the Siona communities for the recuperation of culture through collective meetings, narrative events and the realization of traditional rituals.

During our collaborative work in 2012, I was impressed by his memory and ability to connect different mythic motifs. When revising the "Story of Sun and Moon", a well known motif (See Wheeler (1987) and Langdon (1996)), I came to a line I did not understand about the Moon shouting at Sun to scare him. Felinto said that the line is not clear, since another narrative explains that it is the Owl that screams at the moon. This intertextual comment demonstrated that Felinto had an entire library of narrative texts in his memory, of which I had only heard a few (see Graham 2000). Sadly, our work scheduled for 2012 was interrupted by a series of strokes that rendered him unable to continue.

It was through my discussions with Felinto in 2012 that I first became aware of the language revitalization project and their need for texts to include in the school curriculum. He indicated that they were attempting to stimulate the participation of narrative performances by elders in community gatherings and educational contexts. A few narratives have been published in the Plan de Vida, the most common being that of Pueblo Guayusa, told by the elder Juan Yaiguaje in Siona language and Spanish (Portela Guarín 2003: 63-66). In addition, Wheeler (1987) published over 50 short texts with translations that he elicited during his some 30 years of missionary work among the Siona. The school teachers are familiar with

\footnotetext{
${ }^{4}$ Felinto was also a shaman (taita). The role of Felinto, along with other taitas, is evidenced in the movie produced by ACIPS in 2012: Proyecto Etnoeducativo Zio Bain.
}

his publication, and a few of the texts have also been reproduced in the Plan de Vida (Portela, et al. 2003). There are eight schools in the communities on the Putumayo River, and eight of the 16 teachers are Siona; none of them speak the language (ACIPS 2014: 54-55). Two elders, designated as bilingual sabedores (wise ones), spend periods in the schools in an attempt to teach the language to the teachers and children.

With Felinto's failing health and my desire to continue seeking ways to familiarize the Siona with Felinto's text material as well as my recordings, all photos and recordings were digitalized. A copy of all material was given to the ACIPS president in a field trip in 2013, and the photos were also distributed to the respective families. Through the aid of Pedro Musalem (2016), a doctoral student, the recordings were organized according to narrator and copied onto USB drives. Pedro distributed these in 2014, along with USB players, to the descendants of the narrators.

\section{The Workshop and Narratives}

In August of 2014, we organized a workshop on language revitalization in Mocoa in hopes of familiarizing the Siona with Felinto's texts and their potential for educational use. We invited the Siona teachers, the bilingual sabedores and all elders who still spoke the language. We also invited the President and Vice-President of ACIPS, ACIPS's educational consultant, local officials from the State's Secretary of Education, and the Siona living in Mocoa and Puerto Asis who had interest in attending. Approximately 25 Siona of all ages gathered for two days in which we reviewed five of Felinto's narratives. Felinto was present, but given his poor health, participated minimally in the discussions. Our strategy was to project the narratives on a screen, in Siona and Spanish. José Francisco Piaguaje, an elder trained in teaching and writing the language, ${ }^{5}$ led the group in reviewing the written Siona and translation.

\footnotetext{
5 José Francisco (Pacheco) completed secondary education and had training in ethnolinguistics. He had also worked with Wheeler. Based on Wheeler's work (1987), the Siona have adopted a standardized orthography.
}

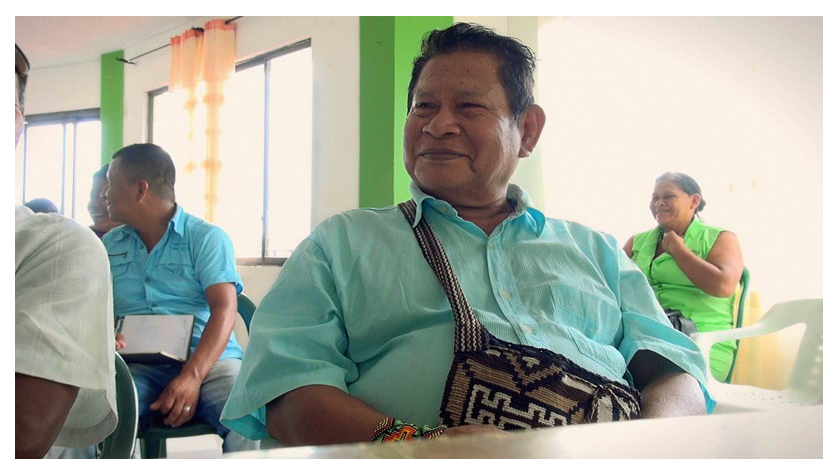

Figure 1. Felinto in workshop, 2014

Figura 1. Felinto en el taller, 2014 


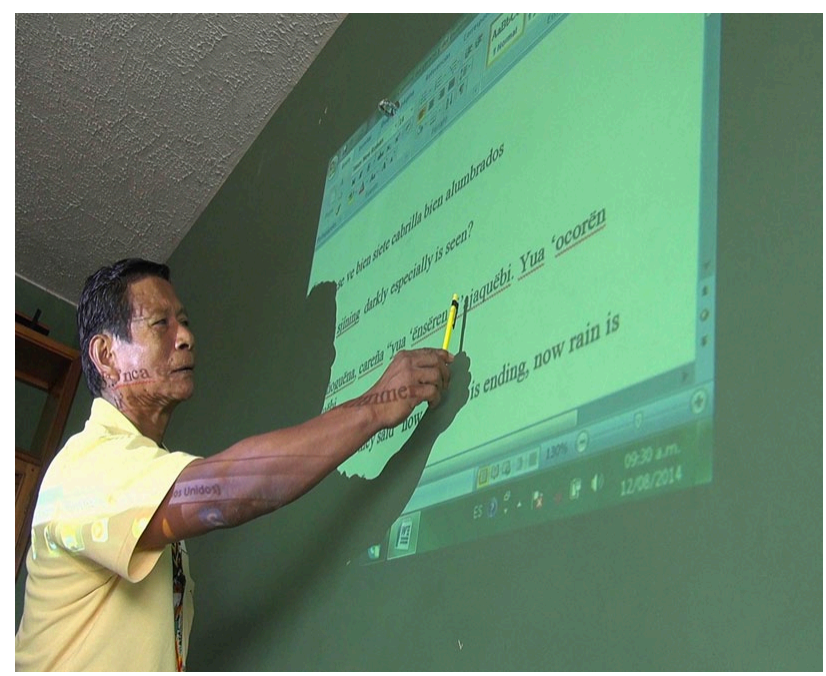

Figure 2. José Francisco leading the workshop

Figura 2. José Francisco liderando el taller

During the two days of the workshop, we were able to review five narratives registered by Felinto: "Naming of San José de Pinuña Blanco and Easter Celebration"; "Community of Santa Elena and the Oyo People"; "Journey to the House of Red Frog"; "Summer Story" and "Winter Story". The first two narratives are histories from the twentieth century that provide details of political and social organization related to the period of the rubber boom, the foundation of communities and traditional celebrations. Juan Yaiguaje, an important contemporary narrator, contextualized both of them, indicating that they were fragments of a much longer history about the movements of the communities on the Putumayo. For that reason, he added, some of the parts were difficult to understand.

Two narratives evoked much discussion and additional narrative performances in the workshop, "Journey to the House of Red Frog" and "Winter Story". Both are important as patrimony, evoking the past and its continuity with the situation in which they find themselves today. In addition, both demonstrate how narrative expresses the differences of perspective and fractal nature of their universe. The first is that told by Laureano Piaguaje to Felinto in 1965.

Journey to the house of Red Frog

1. ja'anrën ira bain yajere uncuni, güebeni, mao ma jojore ëyareña

In that time, the elders drank yajé, became inebriated and saw Red Frog shaman

2. ja'nca ëñato bainguë yajere uncuni, ëñaguëña baguëre

Thus they saw when they drank yajé, they saw him as human.

3. ai ba'i huë'ere baquëña

He had a very large house.

4. ja'an huë'ebi ënsë juinja caguëña baguë

In that house, he was singing Sun chants
5. yaje uncucua ëñañeña baguëre

those who drank yajé saw him

6. ja'nca ëñajëna, baguë quë'rë re'oye achoye juinja caguëña

thus they saw, and he was heard singing even more beautifully.

7. ja'nca cani, tëjini baguë bonëni, ëñaguëña

Finishing singing, he turned and saw them.

8. ja'nrëbi mainre ëñaguëña

Then he saw us.

9. ëñani, caguëña, "ra'jë'ën yë'ëna huajë yëma'ijë'ën" caguëña

He saw and spoke, "come to me, don't be afraid," he said

10. ja'nca caguëna, ti'añeña baguë kuë'ro

Thus inviting, and they entered his house.

11. ja'nca ti'ani, ëñato jai sotorëana jo'cha baguëña Upon entering they saw that he had a large pot of chicha.

12. si'a bain baguëña uti cuare

He had all classes of wasp people.

13. ja'ncua naconi uncuguëña

With them he was drinking.

14. uncujën si'a bain ai güebereña

All were drinking and were very drunk.

15. ja'nca güebeni, bacua ai juinja careña

Thus drunk, they were singing many yajé chants

16. ja'nca carena baguë saquëña yequë huë'ena

Thus they sang, and he took them to another house.

17. ti'ani, caguëña, "yë'ë'ë gañaguë réo juinja caguë He arrived and spoke, "I sing the best chants".

18. "mësacua re'oye juinja ca yëni si'acua jo'chare uncuni, main ira bain cocare achani, juinja ca bi'rayë caguë," quëaguëña bacuare

"Si ustedes quieren cantar bien, tomen toda esta chicha, listen to our elders' words, and begin to sing chants," he said to them

19. uncuaguëña, jo'cha ba jo'cha uncusicua ai güebereña

He gave them chicha, those who drank that chicha were very drunk

20. ja'nca güebeni, güireña

Thus they got drunk and shouted

21. ja'nca güijën oijën uncureña

Thus they shouted, cried and drank

22. ja'nrëbi si'acua juinja ca bi'rareña

Then everyone began to chant.

23. ja'nca juinja carena, baguë ai bojoguë bacuani ëñaguëña

Thus they chanted, and he was very happy seeing them 24. ja'nrëbi rau ëco ëñoguëña si'acuare

Then he showed the remedies to all.

25. "ëñoguë, caguëña, "ën ëco sahuaña sinjobë ëco'ë, ën sahua aña ëco'ë. ën sahua hua'ra rau ëco'ë," ja'nca caguë, si'a rau ëco ëñoguëña

Showing he said, "This plant is remedy for the head; this plant is snake remedy; this plant is remedy for stinging pain," thus speaking he showed all the 
remedies.

26. ja'an caguëna, bacua go'ya rani ëco ëñoreña thus he spoke, and they returned to this side and showed the medicine

27. ja'ancuabi ai re'oye rau sëcoyë

These ones know how to cure very well.

28. ja'nca bacua quërë rau ju'incuare sëconi huachoyë

Thus they rapidly blew and cured the sick ones, they blew and cured

29. ja'nca sëani yure umuguseña bain beoyë ma oma coca cajën ba'isicua

But today there are no people who speak the Red Frog's language

30. yure umuguseña si'acua cayë quë'rë re'oye baë'ë ja'anrëna bain yequë cuaga baëñañe gu'eyë

Today we all say that those of that time lived much better, Those of today don't want to (learn).

The above story is part of a tradition of shamanic narratives that served to explain what to expect when drinking yajé when going to the realm of the Red Frog shaman, or master. As explained in past articles, the ontological and epistemological principles of Siona cosmology are similar to those of other Amazonian groups that have been the object of ethnological discussions since the 1970s (Seeger et al. 1989; Viveiros de Castro, 1996, 2006). The cosmology is marked by the transmutation of forms and appearance depending upon point of view or perspective. It is a transformational world and the distinctions of occidental rationality - nature/culture, animal/human, natural/supernatural - do not operate. The cosmos is composed of a multiplicity of owners/masters and their social communities that reproduce infinitely in a "fractal logic" (Kelly, 2001; Cesarino 2010: 153).

Transformation and change of perspective are expressed by the Siona as two sides. Perception and experience have

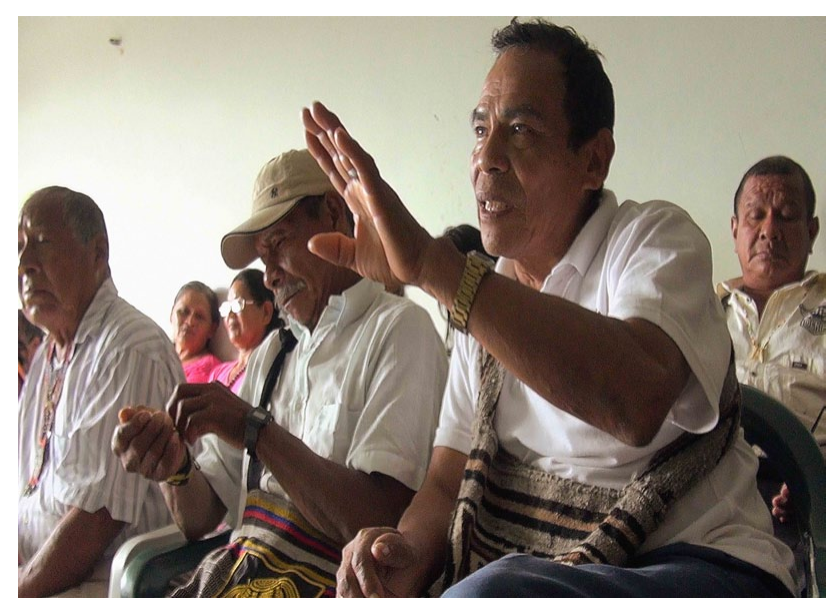

Figure 3. Juan Yaiguaje, Alfonso Senseguaje and Laureano Piaguaje in workshop

Figura 3. Juan Yaiguaje, Alfonso Senseguaje y Laureano Piaguaje en el taller different sides - "this side", the visible ordinary reality and the "other" that is the side of hidden forces that influence and affect the processes of well-being of the collective life. Shamanic practices are oriented to the mastering of travelling in the other side, visiting its numerous realms and accumulating sufficient knowledge to recognize and communicate with the other beings in order to ensure good health or cure illness. Shamanic knowledge is not limited or ever completed, since it is not a finite universe and shamans pass their lifetime visiting and knowing more realms of the universe in order to negotiate with their inhabitants. Shamanic narratives of these experiences served to familiarize novices and apprentices with what to expect when journeying to the different realms. The narrative told by Laureano serves this function, since it is a shaman's journey to the master of the red frogs (mao ma jojo), in order to learn about different remedies. The Siona recognize many different kinds of frogs as important, and the Red Frog is recognized for teaching about remedies for illnesses that involve stinging, biting or have symptoms of stinging pains (piquetes). This is indexed in the narrative by the fact that he is drinking yajé with all different classes of wasps, and later when he teaches the remedies of snake bites and piquetes. To learn these remedies, one ideally journeys to his house.

The narrative conveys a change of perspective that is facilitated by yajé in several lines. Lines two, five and six emphasize the perspective of seeing the frog in its human form and hearing him sing. Perspective is also marked by Frog's invitation to enter, and by entering they see that Wasp People are there drinking chicha with Red Frog. Change of perspective is also marked by the inversion of chicha, the native fermented drink used in festive gatherings, for yajé, the ritual substance used on this side to enter into the fractal world.

Finally, it is important to draw attention to the final lines that lament the passing of this shamanic tradition. This lament contextualizes an important period in Siona history, one in which all the master shamans (including Laureano's father) had died and there was no living Siona with sufficient shamanic knowledge to lead the group in collective yajé rituals that influenced the weather and changing seasons, brought good hunting and fishing, cured illnesses and ensured the general well-being for the community.

The narrator of the "Journey to the House of Red Frog", Laureneano Piaguaje, was present in the workshop. Approximately 85 years of age, he was the only living narrator that I had recorded in the 1970s and had been one of the more lively narrators, speaking rapidly in his Macaguaje dialect and telling many funny animal stories. His son and wife served as his translators in the workshop.

After we reviewed the story he narrated some 55 years ago to Felinto, he told his son that it is difficult to 
reproduce the same story today, that "it is difficult recoger (to gather or pick up) the same theme". Juan Yaiguaje commented that in his youth, Laureano was a lively and funny narrator with a lot of laughing, but that now in "the season of old age" he doesn't remember, finalizing, "It is a problem to gather up the memory. We should try and gather the little that remains; that would be my proposal". Then Laureano's son suggested that he tell a story, and we were witness to a traditional narrative performance. Laureano narrated his personal shamanic experience when he took yajé with his father, a great shaman, and their travels to the house of the shaman frog mao ma.

After he finished, his wife Rosa indicated the parts of the Felinto's story that were incomplete, and then also gave a long narration in Siona about the past, what her father had taught her and all the songs she knew. She told about the festivities when they drank chicha and sang and danced, playing drums and flutes. And she finished with a similar lament, "Now all is over. Beautifully they sang. During the summer, they drank chicha and painted their faces with horizontal lines and little dots that represented the peach palm." She named the elder women who were important in her youth, women who made the chicha and sponsored the parties. "Now there are no grandmothers. No one knows; no one wants to learn. Now there is nothing; few Siona are left".

\section{Winter story}

"Winter Story" was told in conjunction with the "Summer Story" by Emiliano Amo in 1964 and both are related to the change of the seasons by describing the activities of the Sun and Rain people in their heaven realms. "Summer Story" tells of the beginning of the summer in August, marked by the rise of the Pleiades that is associated with the singing of the cicada, bursting of the cotton pods and intensification of agricultural activities and shamanic rituals. Summer ends with the descent of the Pleiades at the edge of the world. "Winter Story" is presented below, since it evoked an important discussion about the

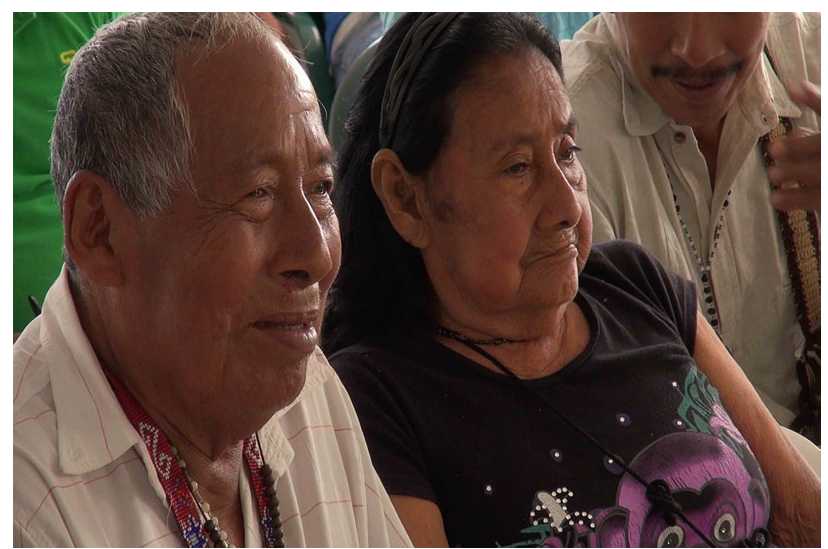

Figure 4. Laureano Piaguaje and Rosa Yaiguaje in workshop

Figura 4. Laureano Piaguaje y Rosa Yaiguaje en el taller ontological relation between the Rain People's activities and those of the Siona before the routine of their lives changed drastically and their environment was destroyed.

\section{1. ocorën coca'ga ñaca quëajën ba'nhuë}

This is story of winter they told.

2. oco re'ohuë bainbi hueare bo'teni, jai sotorona ayani, re'o toani tëoni, ga'toreña

People of the rain region shucked corn and toasted it in a large pot over a big fire.

3. ja'anca ga'tojën, ëama'iñera'ëoñeña

Thus toasting, they burned it really black.

4. ja'anca ëojëna, zi jai pico huëiguëna, ba'boñoabi ba'boñeña mëñe

They burned it, much black smoke rose, and they fanned it upwards.

5. ba'bojën mëoñeña

Fanning, they made it rise.

6. ja'anca picobi mëiguë bacua huë'e yacahuë ca'niguëña

The smoke rose up and gathered in the depths of the roof. ${ }^{6}$

7. bacua ju'i caña'ga güina'ru zije'i caña ca'niguëña And their clothing, in the same way, became black.

8. huea uguë jëhuase're jo'cha ne'ni uncujën pairajën, huatiguan huaiyeña

With the remaining burned corn, they made chicha, drank, danced and beat drums.

9. ja'anca oco bain yo'ojëna mai ba'i réohuë oco bi'raguëña

Thus the Rain people perform and in our realm it begins to rain.

10. oco bain jocha 'uncuni, yajini si'sojëna, ocoguëña The Rain people drinking chicha to the brim, vomit, and it rains on earth.

11. bacua huatiguan huaiyega mënjo cueyeguëña They beat their drums, and thunder sounds.

12. ja'anca quëajën ba'huë ira bain ba cuabi Thus they told, the elder ones.

13. quëajëna, yё'ё achaguë bahuë They told and I listened.

Upon finishing the story, Pedro Musalem asked what was the meaning of ocorën, and Juan Yaiguaje replied, "Ocorën, time of water, of winter. Ocorën means pure clouds of water. We see nothing of the sky, now we don't even see the sun, we are in ocorën". Contextualizing this explanation, he pointed out the window, where all we could see was gray sky on this rainy day.

And his wife, Alba continued,

When the time of winter arrives, what do we elders do, we the Indians? Winter arrived and you couldn't go out to work to do anything. And so they sat to do their tasks, and since there was corn, they sat and shucked

\footnotetext{
${ }^{6} \mathrm{ca}^{\prime} \mathrm{ni}$ - to develop, in the sense that thunderclouds gather to threaten storm
} 
corn in order to make chicha. And they started to toast the corn, this was the task of the ancestors before, and up until now we do it. Alba Maniguaje, abuela

"Winter Story" indexes the relation between different realms that make up the fractal universe of the Siona. Invisible peoples and beings inhabit the other side and operate in non-ordinary space and time. They are divided into different social groups, all of them sharing the same form of socius that exists among the humans and animals on this side. They are owners of their realms or "domains" (re'oto); each group led by a master or owner who cares for his "people" in the same way that the cacique curaca cared for the Siona community in past times. These personified forces affect the activities and cycles of daily life. For example, the Sun, the Rain People and Thunder control the climate and seasonal cycles that affect agricultural production, reproductive cycles of plants and wildlife in the jungle and rivers. During the summer, the Pleiades are high in the sky and it is a period of fruit harvests, agricultural and gathering activities. As they descend to the sunken lake in the east in March, winter arrives and the rains begin. Summer bugs and animals are replaced by winter varieties, and the winter bird, oco chifi, begins to sing his song of rain. The spirits in the forest become more active, and many illnesses are attributed to spirits associated with winter, particularly from those in the jungle rather than the river. Hunting, planting and fishing become reduced during long periods of rain and people withdraw into their homes.

Blanca Alba is telling us that as the Siona ancestors withdrew into their homes, so the Rain people in their realm were settling in and preparing their chicha. The narrative indexes activities in the heaven realm that correspond to routines on this earth. Thus black smoke gathers in the corners of the roof of the Rain People as black clouds gather here. The smoke from the burned corn also blackens the Rain People's tunics, the color of winter. They dance to drums as we hear thunder, and as they fill themselves with chicha and vomit it out, it rains in our realm.

Both the review of the "Summer Story" and of the "Winter Story" also were contextualized by the educational consultant, pointing out that they were related to other aspects of knowledge about the world and environment in Siona culture and how they spoke directly to the seasonal calendar that was being developed for the curriculum.

\section{The workshop and contemporary value of narrative}

The sessions were extremely lively, and the review of the narratives and their translations evoked various discussions about their use in the contemporary context of the ethnoeducational project as well as other activities undertaken for the purposes of the revitalization of culture. There were discussions on the problem of orthographic represention of the different dialects and adequate translation as well as how the texts could be used in the educational context. Like the laments present in the narratives that we were reviewing, the participants also expressed sadness for the loss of language and the need to find ways to preserve their culture, language and way of life. The narratives evoked both memories of the past and responsibilities for the future.

When the missionaries came, they prohibited the Indians from speaking the mother tongue; they took our cultures from us. And with this we came to forget our language and entered modern life. And we are wrong to have lost our customs, culture - all this. They punished us in order to not speak our language - all this, but never have I forgotten, never have I forgotten. I continue thinking that this was ours, this was our equipment. Juan Yaiguaje, abuelo and taita.

There was also present a critical reflection as to the current rejection of the native language and the difficulties of the contemporary context.

The teachers are interested in learning, but if other professors from other ethnic groups come, how are the children going to have the interest in learning? It doesn't exist. If we as native speaking parents say to our children "Speak", they don't. "This has passed, we are civilized, we are now in modern times. This is yours from the past". This is what they say to us now." Alba Maniguaje, abuela.

In the past times of our elders, there existed the possibility of learning and understanding our language, because all the grandfathers and grandmothers present were Siona and they spoke only Bain coca (Our Words). Our own language was taught, it was learned in fishing, in the garden, in the yajé ceremonies and all, and why? Because everything was good: our territory was free. It was not like now when we are totally confined. There is much colonization; many transnational industries are in our territory. The armed conflict that we live today is very critical. It is not like before, when all was possible in the past and now all this is influencing us to forget our culture, to forget our language; all is dying. Yesid Piaguaje, Son of Felinto

However, both the young teachers and the elders present recognized the importance of the narratives for their ongoing revitalization project in the pluricultural and violent situation in which they find themselves.

We have to take advantage of all these histories of our ancestors that they left with the intention of transmitting these memories to the children of our children. Grandfather Ricardo, may he rest in peace, Grandfather Estanislao, Grandfather Luis and also 
Grandfather Aurelio. Okay, all these were united, they told about what they remembered .... Juan Yaiguaje, abuelo and taita

Well if we are letting go of our own maternal tongue, it is because we want to. Our elders are still here, the speakers, those who tell stories and who made traditional food, dances and all of this, the things that drive a people. I believe that this is important, that we as members of our own communities begin with our children to gather up what is being lost.... that they know what have been the steps of our elders - as parents we should begin to compile with our children that which has been left behind.... and I believe that with or without money, we can start. Maria Ligia Paiyoguaje, abuela

The young schoolteachers were also engaged in the dialogue. Many kept detailed notes of the narratives and raised important questions. Several expressed satisfaction in knowing their own narrative tradition rather than just narratives of other indigenous groups and offered suggestions as to how to integrate them into their teaching.

For us having our own narratives is something that motivates us, because it is our own... We must teach western knowledge also, but when we try and find a legend, a myth, it is from other communities, from other peoples, from other states. What motivates us more is our own. Adiela Mera, Teacher in Sitará

I work a lot with this (the narratives), although I don't have many, but I have worked with the "Story of the Garden", the "History of Guayusa". I have worked a lot with these histories and the children like them. To motivate them to draw ..... I believe that as a teacher, this is where the creativity is, in the drawing, and the student has his own motivation when seeing the roots, the roots from where we come, from what we do. Hugo Maniguaje, Teacher in Buena Vista.

The young teachers found that working with the elders gave them new ideas about pronounciation and learning the language.

One of my dreams has been the strengthening of my mother tongue because I see the necessity. As a daughter of the Siona people and one that can't speak the language, this is my greatest task.... Here I had the oportunity to speak a bit to Grandmother Alba and I heard something that I had never heard before and I liked it. She told me from where the pronounciation comes (indicating her nose to express the nazality of the phonemes).....This is something very beautiful, since it is something new in my life; never had I heard this, and I learned it today. Thanks to you and the grandfathers and grandmothers for all this knowledge that you are giving us. Surupa. Adiela Mera, Teacher in Sitará.
At the end of the workshop, they requested written copies of the material, and those with computer access also asked for USB copies of the archives. We added a number of Felinto's other narratives that we had converted to their adopted othography. ${ }^{7}$

If there were the possiblity to leave with us what there is (the texts) in Siona to see how we can advance, because we have to do our part. The work is not of the teachers alone. It is, as we say, the work of the parents, of the grandparents, of the community working with us teachers. I also have my grandmother. She speaks the language and it will be a responsability for me to begin to investigate and to ask. Hugo Maniguaje, Teacher in Buena Vista

\section{Final discussion}

The two narratives are related to ideas of well-being and ways of life that inextricably linked to the activities of the invisible world full of beings that influence daily life. Growth and health, as well as decline and death, are conceived of as cyclic forces reflected in the change of seasons and annual life cycles associated with the passing of the seasons. Siona shamans have been the principle mediators between the invisible beings, warding off evil intentioned beings (huati) as well as contacting the owners of the animals for hunting and the Sun, Thunder and Rain people for stimulating the successful cycling of the seasons and the associated activities. Their rituals, in which they performed mediations with the invisible beings, were collective and intended to maintain wellbeing for the entire community, assuring that both men and women were able to carry out their routine activities and fulfill both their social as well as subsistence responsibilities.

The discussions and interpretations that were raised in the workshop by elders demonstrated clearly the relation between these narratives about daily life and Siona ontology. The narratives convey to their listeners multiple perspectives of daily life and seasonal cycles that express the relation between the visible and material world with the invisible and immaterial. Their importance goes beyond language and touches very deeply on the agenda of cultural revitalization that is outlined in the Plan de Vida (Portela Guarin et al. 2003) and reinforced by the Diagnóstica Salvaguarda (ACIPS 2011). The revisions of the narratives served as an important strategy for evoking memories of past ways of life and local histories that express the Siona notion of well-being or huajë. As an important immaterial patrimony, they play a role in preserving the collective memory as well as in the affirmation of ethnic identity.

\footnotetext{
7 These concerns are all present in the workshop's documentary, "Taller de Bain Coca con el Pueblo Siona del Putumayo", that can be viewed on-line: https://www.youtube.com/watch?v=cBtjW59SWAw
} 


\section{Acknowledgements}

Return trips to the Siona since 2011 and the Workshop in 2014 have been supported by the National Research Instituto Brazil Plural/INCT IBP (CNPq, FAPESC) and by a Productivity Grant from the Conselho Nacional de Tecnologia e Pesquisa/CNPq.

\section{Bibliography}

ACIPS/Asociación de los Cabildos Indígenas Pueblo Siona (2011). ZIO BAIN: Diagnóstico Plan Salvaguarda. ACIPS/Ministerio del Interior, Puerto Asis, Putumayo.

ACIPS/Associación de Cabildos Indígenas del Pueblo Siona (2014). Hoja de Vida. Manuscrito.

Belaunde, L.E. (2001). Viviendo Bien: Género y Fertilidad entre los Airo-Pai de la Amazonía Peruana. Editora CAAP/BCRP, Lima.

Belaunde, L.E., J.A. Echeverri. (2008). El yoco del cielo es cultivado: perspectivas sobre Paullinia yoco en el chamanismo airo-pai (secoyatucano occidental). Anthropologica, 26 (26): 87-112.

Bellier, I. (1991). El Temblor y la Luna. Vol. I e II. ABYA-YALA, Quito.

Burke, K. (1957). Literature as Equipment for Living. The Philosophy of Literary Form. pp. 253-262, Vintage Books, New York.

Candre-Kinerai, H. and J.A. Echeverri (1993). Tobaco Frío, Coca Dulce. Colcultura, Bogotá.

Candre, H. and J.A. Echeverri. (1996). Cool Tobacco, Sweet Coca: Teachings of an Indian Sage from the Colombain Amazon. Themis Books, England.

Casas-Manrique, M. and M. de Castellví. (1940) ms. "Encuesta siona y eno". Manuscript in the archives of Centro de Investigaciones Lingüisticas y Etnográficas de la Amazonía Colombiana (CILEAC), Bogotá, Colombia

Cesarino, P. de N. (2010). Donos e Duplos: relações de conhecimento, propriedade e autoria entre Marubo, Revista de Antropologia, 53 (1) : 147-197.

Chaves Chamorro, M. (2002). Jerarquías de color y mestizaje en la Amazonia occidental colombiana. Revista Colombiana de Antropologia 38: $189-216$

Chaves Chamorro, M. (2003). "Cabildos multiétnicos e identidades depuradas". C.I. Garcia, Ed. Fronteras territories y metáfora, pp. 121135, Instituto de Estudios Regionales, INER, Universidad de Antioquia, Hombre Nuevo Editores, Medellín.

Cipolletti, M.S. (1988). Aipe Koka: La palabra de los antiguos. Tradición oral secoya. Ediciones ABYA-YALA, Quito, Ecuador.

Corte Constitucional (2009). Auto no. 004 de 2009. http://www.mintic. gov.co/portal/604/articles-3486_documento.pdf (Last access 20/09/2016)

Echeverri, J.A. ed. (2004). “Botando Pereza : El Yoco entre los secoya del Putumayo. Leticia, Universidad Nacional de Colombia.

Graham, L.R. (2000). "The One who created the sea": Tellings, meanings and intertextuality in the translation of Xavante narrative." K. Sammons and J. Sherzer, ed. Translating Native Latin American Verbal Art: Ethnopoetics and Ethnography of Speaking. pp. 252-271, Smithsonian Institution Press,

Kelly Luciani, J.A. (2001). Fractalidade e Troca de Perspectivas, Mana, 7(2): 95-132.
Kienzl, S. (2006). Informe Preparatorio para la Mision Internacional de Verificación de la Situación de derechos humanos y derecho internaiconal humanitario en pueblos Indígenas en Colombia. http://www.acnur.org/ t3/uploads/media/1647.pdf?view=1 (Last Access 19/09/2016).

Langdon, E.J. (1990). La historia de la conquista de acuerdo a los Indios Siona del Putumayo. R. Pineda Camacho and B. Alzate Angel, ed. Los Meandros de la Historia em Amazônia, pp. 13-41. Ediciones Abya-Yala, Quito, Ecuador.

Langdon, E.J. (1996). Mueren en realidad los chamanes? narracciones de los siona sobre chamanes muertos. Alteridades, Antropologia de la curación. 6(12): 61-75.

Langdon, E.J. (2001). A Doença como Experiência: O Papel da Narrativa na Construção Sociocultural da Doença. Etnográfica: Revista do Centro de Estudos de Antropologia Social. V(2):241-260.

Langdon, E.J. (2013). "La visita a la casa de los tigres": La contextualización en narrativas sobre experiencias extraordinarias. Revista Colombiana de Antropologia 49(1): 129-152

Langdon, E.J. (2014). La negociación de lo oculto: chamanismo, medicina y familia entre los Siona del bajo Putumayo. Editora Universidade del Cauca, Popayán, Colombia.

Langdon, A.S. and E.J., directors. (2015). Taller de Bain Coca con el Pueblo Siona del Putumayo. 30 min. INCT: Instituto Brasil Plural, Florianópolis.

Mallol de Recasens, M.R. (1963). Cuatro representaciones de las imagenes alucinatorias originadas por la toma del yagé. Revista Colombiana de Folclor (Bogotá) III(8): 59-79.

Mallol de Recasens, M.R. and J. de Recasens T. (1964-65). Contribución al conocimiento del cacique-curaca entre los Siona. Revista Colombiana de Antropología (Bogotá) 13:91-145.

Musalem Nazar, P. (2015). Circuitos políticos en el Putumayo indígena. Paper presented in the XV Congreso de Antropología en Colombia: Regiones, "Postconflicto" y Futuros Posibles. June, Santa Marta, Colômbia

Musalem Nazar, P. (2016). Os Siona do Putumayo: Memoria, Historia e Ritual. Programa de Pós-Graduação em Antropologia, Universidade Federal de Santa Catarina, Brazil. Doctoral Thesis, Biblioteca, UFSC.

Overing, J. and A. Passes, ed. (2000). The anthropology of Love and Anger: The Aesthetics of conviviality in Native Amazonia. Routledge, London.

Portela Guarín, H., et. al. (2003). Plan de vida del pueblo Siona Ga'ntëya bain. Editorial Universidad del Cauca, Popayán.

Ramírez, M.C. (2011). Between the Guerrrillas and the State: The Cocalero Movement, Citizenship and Identity in the Colombian Amazon. Duke University Press, Durham.

Seeger, A., R. DaMatta, E. Viveiros de Castro (1987). A Construção da Pessoa nas Sociedades Indígenas Brasileiras". Pacheco de Oliveira Filho, J. ed., Sociedades Indígenas e Indigenismo no Brasil, pp. 11-30. UFRJ/ Editora Marco Zero, Rio de Janeiro.

Vickers, W. (1989). Los Sionas y Secoyas: Su adaptación al medio ambiente amazónico. ABYA-YALA, Quito.

Viveiros de Castro, E.B. (1996). Os Pronomes Cosmológicos e o Perspectivismo Amerindio. Mana, 2 (2): 145-162.

Viveiros de Castro, E.B. (2006). A Floresta de Cristal: Notas sobre a Ontologia dos Espíritos Amazônicos. Cadernos de Campo 14/15: 319-338

Wheeler, A. (1987). Gantëya bain (El pueblo siona del río Putumayo, Colombia). 2 vol. Instituto Lingüístico de Verano, Bogotá. 